Provided for non-commercial research and education use. Not for reproduction, distribution or commercial use.

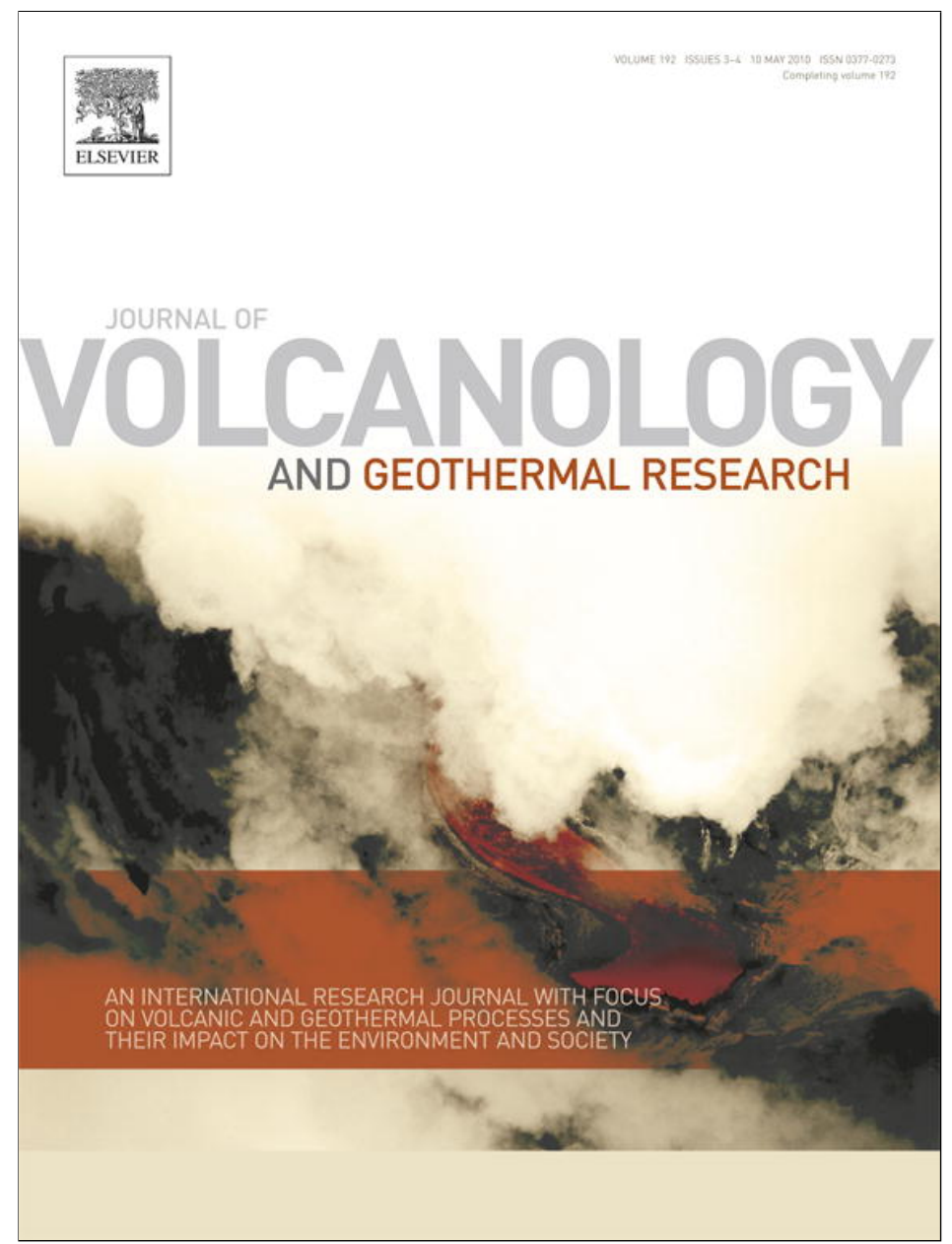

This article appeared in a journal published by Elsevier. The attached copy is furnished to the author for internal non-commercial research and education use, including for instruction at the authors institution and sharing with colleagues.

Other uses, including reproduction and distribution, or selling or licensing copies, or posting to personal, institutional or third party websites are prohibited.

In most cases authors are permitted to post their version of the article (e.g. in Word or Tex form) to their personal website or institutional repository. Authors requiring further information regarding Elsevier's archiving and manuscript policies are encouraged to visit:

http://www.elsevier.com/copyright 


\title{
Magma degassing process during Plinian eruptions
}

\author{
Lorraine Ruzié, Manuel Moreira* \\ Institut de Physique du Globe de Paris, Equipe de Géochimie et Cosmochimie, Université Paris Diderot et CNRS UMR7154, 4 place Jussieu, 75005 Paris, France
}

\section{A R T I C L E I N F O}

\section{Article history:}

Received 14 April 2009

Accepted 28 February 2010

Available online 12 March 2010

\section{Keywords:}

noble gases

Plinian eruption

pumice

magma kinetic degassing

\begin{abstract}
A B S T R A C T
To assess magma degassing processes during Plinian eruption, noble gas abundances and isotopic ratios have been determined in pumices by crushing under vacuum. Samples come from Plinian eruptions, which occur along different subduction zones. In addition, two pumice samples come from the Azores hotspot. All samples are characterized by a systematic enrichment in neon over argon, a depletion of krypton relative to argon and an isotopically fractioned ${ }^{38} \mathrm{Ar} /{ }^{36} \mathrm{Ar}$ ratio. These features do not depend on geological setting, or on pumice age, or eruption intensity. However, they are similar for pumices from the same eruption. A correlation is observed between ${ }^{84} \mathrm{Kr} /{ }^{36} \mathrm{Ar}$ and the ${ }^{38} \mathrm{Ar} /{ }^{36} \mathrm{Ar}$ ratio. This illustrates that only one physical process is at the origin of the fractionation. We propose here a model of kinetic magma degassing before fragmentation to explain the elemental and isotopic fractionation. Noble gases diffuse in a magma shell surrounding a preexisting bubble. The model put forward an alternative to the model of Pinti et al. (1999), in which diffusion occurs after pumice quenching in Plinian plume. The model explains measurements and shows the rapidity of the magma degassing process in the conduit (few hundreds of seconds).
\end{abstract}

(c) 2010 Elsevier B.V. All rights reserved.

\section{Introduction}

The style and intensity of explosive volcanic eruptions depend primarily on the mechanism and the rate of magmatic vesiculation. During magma ascent, melt becomes supersaturated with respect to volatiles by decompression and exsolves an independent gas phase in an attempt to reestablish both thermodynamic and chemical equilibrium (Mangan and Sisson, 2000). Bubbles start to grow by gas diffusion from the magma into the bubble (Fig. 1). The exsolution is mainly driven by solubility and by diffusion. Fragmentation occurs when the volume fraction of gas bubbles in a vesicular magma exceeds a threshold value (Sparks, 1978). Fragmentation is also taken to mark a change in the flow dynamics, from a laminar regime involving viscous and vesicular magma to a turbulent regime involving a mixture of gas and suspended fragments. After fragmentation, gas partitions between two different phases: a continuous phase, which separates magma fragments and a second phase of bubbles within fragments (Kaminski and Jaupart, 1998). Magma fragments spend then a few seconds in the volcanic conduit and several tens of seconds in the eruption Plinian column (Thomas et al., 1994). They remain liquid for several seconds before being quenched. In this study, degassing induced by diffusion of volatile species in the melt is investigated.

Pumice is a highly vesicular glass produced by fragmentation of a volatile enriched magma. Pumice in which some vesicles are

\footnotetext{
* Corresponding author.

E-mail address: ruzie@ipgp.jussieu.fr (M. Moreira).
}

preserved could retain information on the gaseous phase implicated during the eruption. Pinti et al. (1999) measured noble gas abundance and neon and argon isotopic composition in pumice samples from Japan and the Eolian islands (Italy). Noble gases are an effective geochemical tool to provide constraints on degassing processes because they are chemically inert. The authors suggest that the large excess of neon over argon is produced by preferential diffusion of neon in pumice vesicles through bubble walls. In that case, diffusion occurs after pumice quenching in the Plinian plume.

In our study, we carried out noble gas measurements in pumices from various geological settings. We propose here a new model to explain our dataset that displays both elemental and isotopic fractionations. The isotopic ratio ${ }^{38} \mathrm{Ar} /{ }^{36} \mathrm{Ar}$ shows an isotopic fractionation rarely observed in terrestrial samples. This observation leads us to develop a magma kinetic degassing model and to suggest that the fragmentation process occurred in only few minutes.

\section{Samples and their geological setting}

We studied two different geological settings: subduction zones (Lesser Antilles, Cascades and New Zealand) and a hotspot (Azores) in an attempt to demonstrate a hypothetical link between measured isotopic ratios and tectonic setting. Furthermore, the studied pumices exclusively belong to Plinian falls from well-studied eruptions.

\subsection{Lesser Antilles}

Westward subduction of the Atlantic plate at $\sim 2.2 \mathrm{~cm} / \mathrm{yr}$ has given rise to the Lesser Antilles, a 750-km long intra-oceanic north-south- 


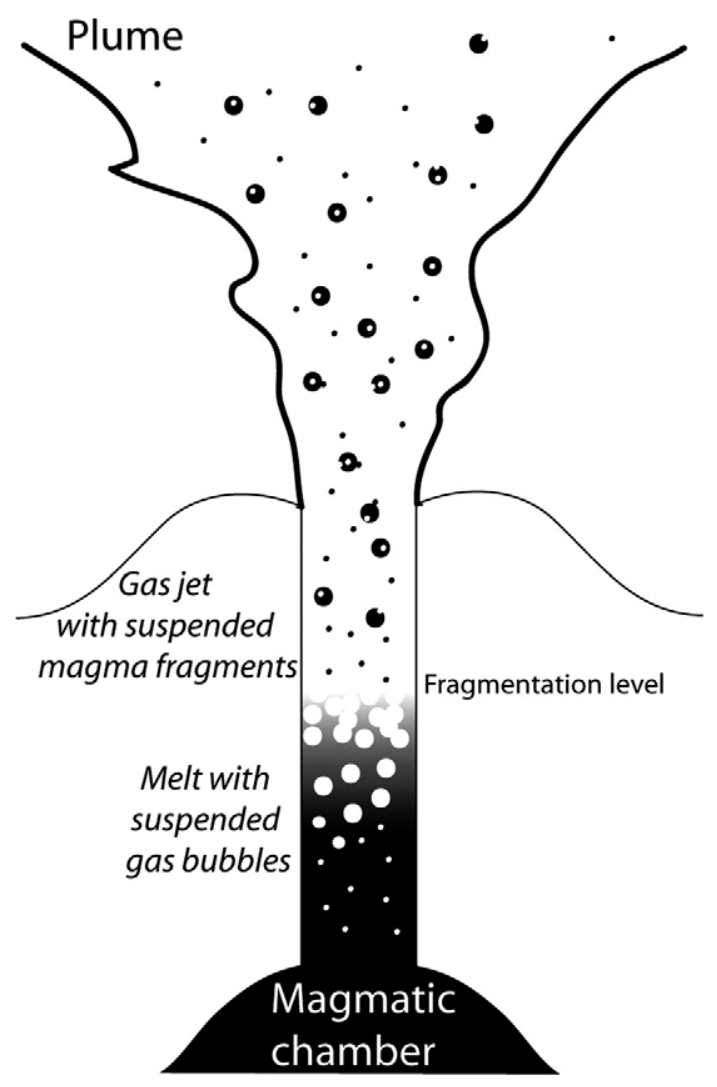

Fig 1. Illustration of the fragmentation process involved in a Plinian eruption. Magma clasts (e.g. pumices) are generated by the fragmentation at some depth in the conduit.

trending volcanic arc, located on the eastern margin of the Caribbean plate. Mt Pelée (Martinique, FWI) is one of the active stratovolcanoes of the Lesser Antilles Island Arc. Stratigraphic studies of Mt Pelée have revealed six Plinian eruptions in the last 5000 years and 12 domeforming eruptions. The P1 eruption in the nomenclature of Westercamp and Traineau (1983) is the last Plinian event recorded at Mt Pelée (dated to $650 \pm 20$ years BP) preceded by the P2 Plinian event ( $1670 \pm 40$ years BP). The eruption P2 starts with Plinian activity and produced ash fall deposits in the volcano northern flank. This activity is followed by nuées ardentes in the East and Southwest valleys. P1 eruption begins phreatic to phreatomagmatic activity, followed by nuées ardentes. Just after, the Plinian phase occurred.

\subsection{New Zealand}

New Zealand in the South-Pacific belongs to the "Ring of Fire". The Taupo Volcanic Zone (TVZ) is the dominant locus of late Pliocene to Quaternary volcanic activity in New Zealand. This activity is the result of subduction of the Pacific Plate beneath the North Island, which is build on continental crust (Wilson et al., 1995).

Lake Taupo, the largest lake in New Zealand, owes its existence and shape to the caldera-forming eruption of the Taupo volcano. The enormous Oruanui eruption, which occurred 26,500 years ago, formed a $30-\mathrm{km}$ wide depression. The most recent major eruption of Taupo volcano took place around 1800 years ago. The eruption column rose about $50-\mathrm{km}$ high. The analyzed pumice seems to belong at the latter eruption (Wilson et al., 1995 and references therein).

Mt Ruapehu (2797 m) is the largest andesite-dacite volcano with $\sim 10 \mathrm{~km}^{3}$ in the TVZ. The 1945 and 1995-1996 eruptions were the two largest volcanic events in New Zealand this century. The last eruption started 18th September 1995 with phreatomagmatic eruptions. In the middle of October, three sub-Plinian explosions occur. After 8 months of relative quiescence, a second phreatomagmatic eruption initiates a more prolonged period of eruptive activity, which culminates in Strombolian-type eruptions in July 1996 (Christenson, 2000). The analyzed pumice belongs to the next to last event.

\subsection{Azores}

The Azores Archipelago is composed of nine islands, which represent the emerged part of a large oceanic platform, located at the triple junction between Eurasian, African and American plates. Seven of the nine islands are located east of the Mid-Atlantic ridge. The last two islands are located to the west of the ridge, on the American plate (Moore, 1990).

São Miguel is the largest $(62 \times 13 \mathrm{~km})$ and most populous (about 150,000 inhabitants) of the nine islands. During the past 500 years, five eruptions have occurred, of which three are trachytic events. Five geological units constitute São Miguel, from West to East: Sete Citades stratovolcano, Picos area with its mafic lavas, Fogo stratovolcano, known as Agua de Pau, Furnas stratovolcano, Nordeste volcano with Pavoação caldera. We sampled only Furnas and Fogo units, because these volcanoes have produced historical eruptions (Moore, 1990).

Volcanic activity at Furnas spans the last 100,000 years. Furnas has been the site of at least ten explosive eruptions in the last 5000 years. The two historical eruptions 1439-1443 (Gaspar) and 1630 AD took place within the caldera. For these two eruptions, effusive activity followed explosive activity building a trachytic lava dome within the tuff ring complex formed during the earlier explosive phase (Cole et al., 1995). Pumices come from the horseshoe-shaped tuff ring. The volcano which ceased activity in $1563 \mathrm{AD}$ produced Fogo pumices.

Terceira, the third largest island in the Azores archipelago is constructed from three volcanic centers built by basaltic to trachytic lava flows and pyroclastic deposits (Calvert et al., 2006). One sample comes from Santa Barbara, the youngest volcano of the island. The other one belongs to Pico Alto, the active north flank of the central volcano, Guilherme Moniz.

\subsection{St. Helens}

Mount St. Helens along with 32 other volcanoes belongs to the North American continental arc, resulting from the subduction of the Juan de Fuca oceanic plate. Mt St. Helens awoke with the onset of significant shallow earthquakes on March 20, 1980. The eruption started on March 27, 1980 as a series of phreatomagmatic explosions. The cryptodome intrusion in April triggered collapse of the north flank on May 8, 1980. This massive landslide is followed by minor explosive activity and the formation of a vertical eruption column. Explosive eruptions continue to occur until October (Scandone et al., 2007 and references therein).

\section{Analytical procedure and results}

Pumice samples were loaded in a crusher and baked overnight at $50{ }^{\circ} \mathrm{C}$ under ultra-high vacuum to remove gas adsorbed on the surface. Crushing was used to extract gases from the samples. Gases were purified using two hot Ti-getters. The noble gases were then adsorbed on charcoal at a temperature around $10 \mathrm{~K}$. The five noble gases (He, $\mathrm{Ne}, \mathrm{Ar}, \mathrm{Kr}$, and $\mathrm{Xe}$ ) were separated from each other by selective desorption from the charcoal at $30 \mathrm{~K}, 70 \mathrm{~K}, 130 \mathrm{~K}, 160 \mathrm{~K}$ and $320 \mathrm{~K}$, respectively. Gas contents and isotopic compositions were analyzed with the mass spectrometers ARESIBO I and II. ${ }^{4} \mathrm{He}$ and ${ }^{40} \mathrm{Ar}$ were analyzed on a Faraday cup whereas the other isotopes were analyzed using an electron multiplier equipped with an ion counting system. Blanks were performed before each sample. For instance ${ }^{4} \mathrm{He},{ }^{22} \mathrm{Ne}$, ${ }^{36} \mathrm{Ar},{ }^{84} \mathrm{Kr}$ and ${ }^{130} \mathrm{Xe}$ blanks on Aresibo I were $1.8 \times 10^{-8}, 2.6 \times 10^{-12}$, $1.6 \times 10^{-11}, 1.6 \times 10^{-13}$ and $1.9 \times 10^{-15} \mathrm{ccSTP} / \mathrm{g}$, respectively.

Tables $1 \mathrm{a}$ and $1 \mathrm{~b}$ give the concentrations and isotopic ratios of the noble gases in the analyzed pumices. Helium abundances are often 
Table 1a

Noble gas abundances and isotopic ratios measured in pumice from Martinique, New Zealand, Azores and St. Helens.

\begin{tabular}{|c|c|c|c|c|c|c|c|c|c|c|c|c|c|c|c|}
\hline Area & Sample & Spectro & $\begin{array}{l}{ }^{4} \mathrm{He} \\
\left(\times 10^{-7}\right)\end{array}$ & $\begin{array}{l}{ }^{22} \mathrm{Ne} \\
\left(\times 10^{-8}\right)\end{array}$ & $\begin{array}{l}{ }^{36} \mathrm{Ar} \\
\left(\times 10^{-9}\right)\end{array}$ & $\begin{array}{l}{ }^{84} \mathrm{Kr} \\
\left(\times 10^{-12}\right)\end{array}$ & $\begin{array}{l}{ }^{130} \mathrm{Xe} \\
\left(\times 10^{-13}\right)\end{array}$ & ${ }^{20} \mathrm{Ne} /{ }^{22} \mathrm{Ne}$ & S & ${ }^{21} \mathrm{Ne} /{ }^{22} \mathrm{Ne}$ & S & ${ }^{38} \mathrm{Ar} /{ }^{36} \mathrm{Ar}$ & S & ${ }^{40} \mathrm{Ar} /{ }^{36} \mathrm{Ar}$ & S \\
\hline & Air & & & & & & & 9.8 & & 0.029 & & 0.188 & & 296 & \\
\hline \multirow[t]{10}{*}{ Martinique P1 } & G & II & & 9.0 & 71.1 & 933.2 & 48.3 & 9.86 & 2.02 & 0.0289 & 0.0003 & 0.1867 & 0.0004 & 299 & 2 \\
\hline & G & I & & 4.4 & & & & 9.79 & 0.01 & 0.0290 & 0.0001 & & & & \\
\hline & $\mathrm{F}$ & I & & 5.9 & & & & 9.81 & 0.02 & 0.0291 & 0.0001 & & & & \\
\hline & Fbis & II & & 8.7 & 40.3 & 620.0 & 29.5 & 9.79 & 0.03 & 0.0291 & 0.0003 & 0.1871 & 0.0004 & 290 & 2 \\
\hline & D3 & I & & 5.8 & & & & 9.82 & 0.01 & 0.0289 & 0.0001 & & & & \\
\hline & D3 & II & & 9.6 & 38.6 & 441.9 & & 9.83 & 0.02 & 0.0290 & 0.0006 & 0.1859 & 0.0003 & 296 & 2 \\
\hline & D3 & II & 4.3 & 12.4 & 51.7 & 716.4 & 45.7 & 9.85 & 0.04 & 0.0288 & 0.0002 & 0.1871 & 0.0004 & 286 & 3 \\
\hline & $\mathrm{H}$ & II & 0.9 & 7.8 & 89.6 & 1091.1 & 55.7 & 9.69 & 0.07 & 0.0287 & 0.0003 & 0.1870 & 0.0003 & 294 & 4 \\
\hline & $\mathrm{H}$ & I & & 8.1 & & & & 9.80 & 0.01 & 0.0290 & 0.0001 & & & & \\
\hline & C3 & II & 5.5 & 8.2 & 33.8 & 435.0 & 26.6 & 9.79 & 0.07 & 0.0289 & 0.0003 & 0.1868 & 0.0004 & 297 & 4 \\
\hline \multirow[t]{12}{*}{ Martinique P2 } & R52a & I & & 2.4 & & & & 9.77 & 0.02 & 0.0289 & 0.0001 & & & & \\
\hline & R52T & I & & 1.5 & & & & 9.79 & 0.02 & 0.0289 & 0.0002 & & & & \\
\hline & R52um & I & & 1.8 & & & & 9.78 & 0.01 & 0.0289 & 0.0001 & & & & \\
\hline & R52 & II & 4.2 & 3.2 & 0.3 & 7.1 & & 9.84 & 0.02 & 0.0288 & 0.0001 & & & & \\
\hline & R52 & II & & 2.0 & 0.3 & 5.7 & & 9.86 & 0.03 & 0.0287 & 0.0002 & 0.1879 & 0.0007 & 294 & 5 \\
\hline & R52 & I & 0.2 & 2.2 & 0.3 & 3.2 & 0.4 & 9.78 & 0.06 & 0.0295 & 0.0002 & 0.1863 & 0.0005 & 309 & 9 \\
\hline & $\mathrm{R} 52 \mathrm{~b}$ & I & & 0.7 & 0.1 & 1.6 & 0.3 & na & na & 0.0286 & 0.0008 & 0.1858 & 0.0006 & 305 & 4 \\
\hline & R54up & I & & 0.7 & 0.6 & 14.8 & 1.7 & 9.79 & 0.01 & 0.0289 & 0.0002 & 0.1889 & 0.0002 & 295 & 3 \\
\hline & R56 & I & & 0.7 & 0.1 & 0.7 & 0.4 & 9.70 & 0.02 & 0.0290 & 0.0003 & 0.1839 & 0.0006 & 299 & 4 \\
\hline & $\mathrm{R} 56 \mathrm{~b}$ & I & & 2.4 & & & & 9.77 & 0.02 & 0.0290 & 0.0001 & & & & \\
\hline & $\mathrm{R} 56 \mathrm{~m}$ & I & & 0.8 & & & & 9.77 & 0.02 & 0.0291 & 0.0002 & & & & \\
\hline & R53ub & I & & 1.0 & & & & 9.79 & 0.02 & 0.0292 & 0.0002 & & & & \\
\hline \multirow[t]{3}{*}{ New Zealand } & Tuapo & I & 3.0 & 14.9 & 17.0 & 348.2 & 17.9 & 9.73 & 0.05 & 0.0290 & 0.0002 & 0.1890 & 0.0004 & 299 & 9 \\
\hline & Tuapo2 & I & 1.5 & 16.2 & 11.5 & 245.0 & 9.6 & 9.71 & 0.05 & 0.0288 & 0.0002 & 0.1886 & 0.0004 & 298 & 9 \\
\hline & Ruapehu & I & & 2.1 & 14.6 & 212.9 & 7.1 & 9.82 & 0.05 & 0.0291 & 0.0002 & 0.1875 & 0.0006 & 301 & 9 \\
\hline \multirow[t]{4}{*}{ Sao Miguel } & INZ31 & I & 5.8 & 0.9 & 12.5 & 193.9 & 7.9 & 9.89 & 0.05 & 0.0290 & 0.0003 & 0.1876 & 0.0004 & 295 & 9 \\
\hline & INZ35 & I & 8.3 & 14.0 & 109.5 & 1927.3 & 78.2 & 9.69 & 0.05 & 0.0291 & 0.0002 & 0.1871 & 0.0004 & 298 & 9 \\
\hline & INZ36 & I & 6.3 & 4.1 & 4.5 & 78.1 & 4.1 & 10.01 & 0.05 & 0.0292 & 0.0002 & 0.1888 & 0.0006 & 302 & 9 \\
\hline & INZ39 & I & & 0.8 & 5.4 & 41.0 & 1.7 & 9.87 & 0.05 & 0.0294 & 0.0002 & 0.1856 & 0.0006 & 283 & 9 \\
\hline \multirow[t]{2}{*}{ Terceira } & T406 & I & 0.3 & 1.2 & 0.9 & 10.1 & 1.3 & 9.76 & 0.05 & 0.0288 & 0.0002 & 0.1865 & 0.0004 & 285 & 8 \\
\hline & $\mathrm{T} 412$ & I & 3.8 & 4.4 & 109.3 & 1828.5 & & 9.72 & 0.03 & 0.0291 & 0.0001 & 0.1862 & 0.0001 & 282 & 4 \\
\hline \multirow[t]{3}{*}{ Cascades } & St. Helens & I & & 1.5 & 5.0 & 215.8 & 39.1 & 9.89 & 0.05 & 0.0295 & 0.0002 & 0.1887 & 0.0004 & 298 & 9 \\
\hline & St. Helens & I & & 4.4 & 9.9 & 204.5 & 14.0 & 9.93 & 0.03 & 0.0290 & 0.0001 & 0.1876 & 0.0002 & 286 & 4 \\
\hline & St. Helens & I & & 2.2 & 7.3 & 173.8 & 7.6 & 9.98 & 0.06 & 0.0295 & 0.0003 & 0.1881 & 0.0004 & 296 & 9 \\
\hline
\end{tabular}

close to the blank value and will not be used in this study. ${ }^{20} \mathrm{Ne} /{ }^{22} \mathrm{Ne}$ ratios fall between 10.01 and 9.69 , close to the air ratio $(9.8) .{ }^{21} \mathrm{Ne} /$ ${ }^{22} \mathrm{Ne}$ ratios do not show significant variation compared to the atmospheric ratio. The ${ }^{38} \mathrm{Ar} /{ }^{36} \mathrm{Ar}$ ratios obtained for this study fluctuate between 0.1839 and 0.1890 , showing an important isotopic fractionation, compared to the air ratio (0.188). The ${ }^{40} \mathrm{Ar} /{ }^{36} \mathrm{Ar}$ ratios are close the air value (296). For some samples, we have also analyzed all the isotopes of krypton and xenon (Table 1b). But most of time, uncertainties are too large to observe isotopic fractionations compared to air.

\subsection{Abundances}

In Fig. 2, the elemental noble gas abundance patterns were represented as the fractionation factor $F(x)$ where $F(x)=\left(x /{ }^{36} \mathrm{Ar}\right) /$ $\left(x{ }^{36} \mathrm{Ar}\right)_{\text {air }}$. The global trend is quite similar for all pumices. The value of $F\left({ }^{22} \mathrm{Ne}\right.$ ) has a wide range from 1625 (P2, Martinique) to 13 (Sao Miguel, Azores). With all samples displaying significant neon enrichment compared to air value. $F\left({ }^{84} \mathrm{Kr}\right)$ values are generally below the air value except for R54 (P2) and St. Helens which show higher ratios. Finally, the $F\left({ }^{130} \mathrm{Xe}\right)$ values are lower than 1 except for P2, St. Helens and one pumice of Terceira.

For Martinique, three different patterns appear. P1 pumices show a similar pattern for the five samples, which belong to the same stratigraphic level. P2 pumices all share the same pattern, clearly distinct from the P1 pumices. Here a third pattern looms. For that pumice, field identification is quite uncertain and it could be linked to an older Plinian eruption (Kaminski, perso. comm). This assumption should be confirmed by dating. To conclude, this first graphic displays that abundance patterns are similar for a single eruption.

For the New Zealand samples, Taupo pumices all show a similar pattern which is different from the Ruapehu pumice. Taupo pumices display a lower fractionation factor $F\left({ }^{22} \mathrm{Ne}\right)$ than Martinique samples. Therefore, the size of the Plinian plume, which has been determined at a 50-km height for Taupo eruption (super eruption), has no influence on the degree of noble gas fractionation. In other words, the time spent by the pumice within the plume is not determinant in the abundance pattern.

Finally, Azores hotspot pumices do not present a single abundance pattern, although the geological setting is totally different compared to the previous ones.

In summary, fractionation factors do not depend on geological setting, or the height of the Plinian plume, or on pumice age. However, within a single eruption, the observed fractionations are similar.

\subsection{Isotopic ratios}

The neon isotopic ratios are quite similar to air isotopic ratios. On Fig. 3, samples above the air value show enrichment in light isotopes. On the contrary, samples below the air value show a relative enrichment in the heavier isotopes. Samples fall on the mass fractionation line $(\mathrm{mfl})$ within uncertainties.

${ }^{38} \mathrm{Ar} /{ }^{36} \mathrm{Ar}$ isotopic ratios are clearly distinct from air ratio, showing an anomalous fractionation rarely observed on Earth. The lowest measured value is $0.1839 \pm 0.0006$ for R56 sample (P2-Martinique). Fig. 4 shows a correlation between $F\left({ }^{84} \mathrm{Kr}\right)$ and ${ }^{38} \mathrm{Ar} /{ }^{36} \mathrm{Ar}$ suggesting 


\section{Author's personal copy}

L. Ruzié, M. Moreira / Journal of Volcanology and Geothermal Research 192 (2010) 142-150

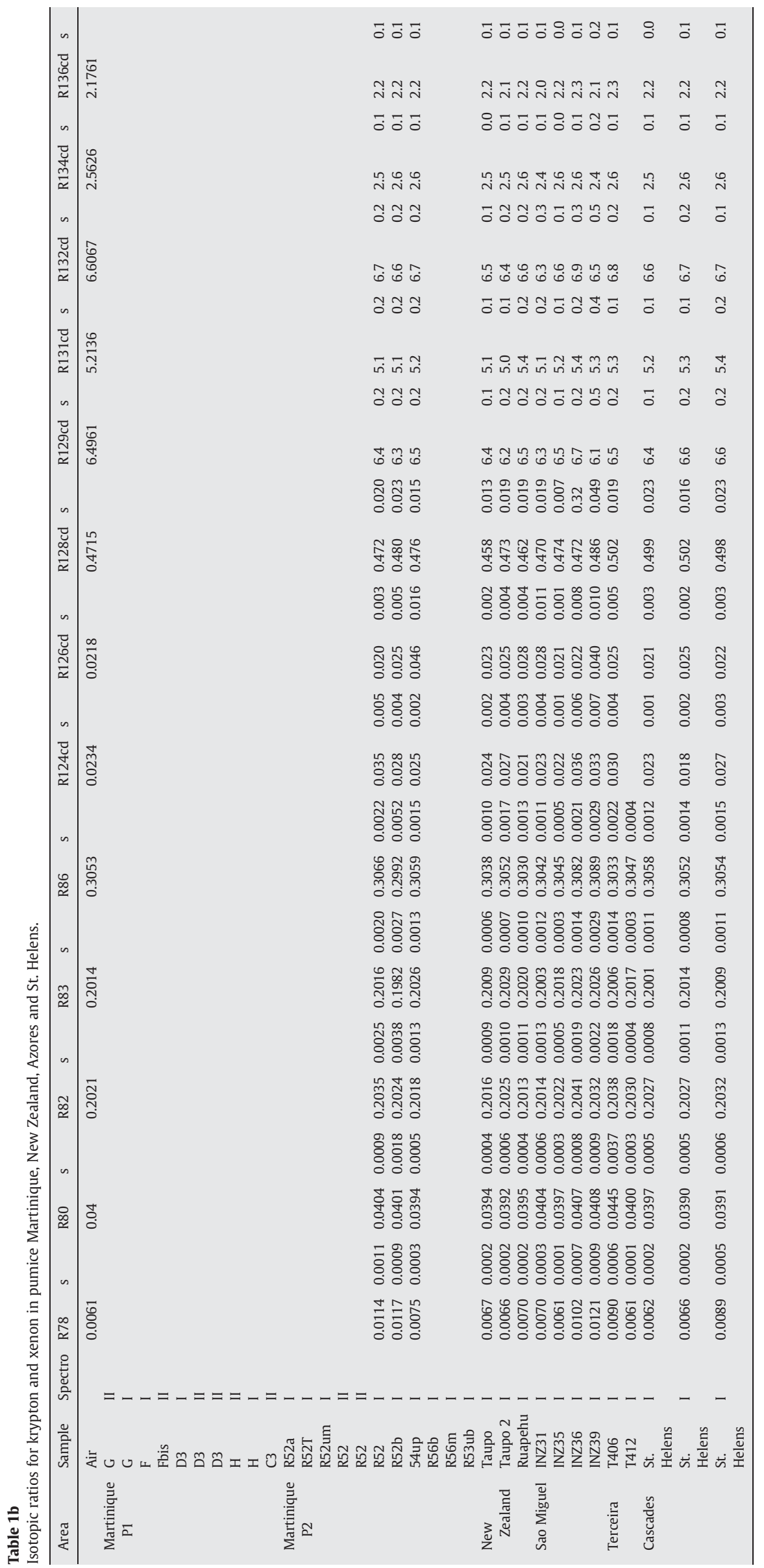



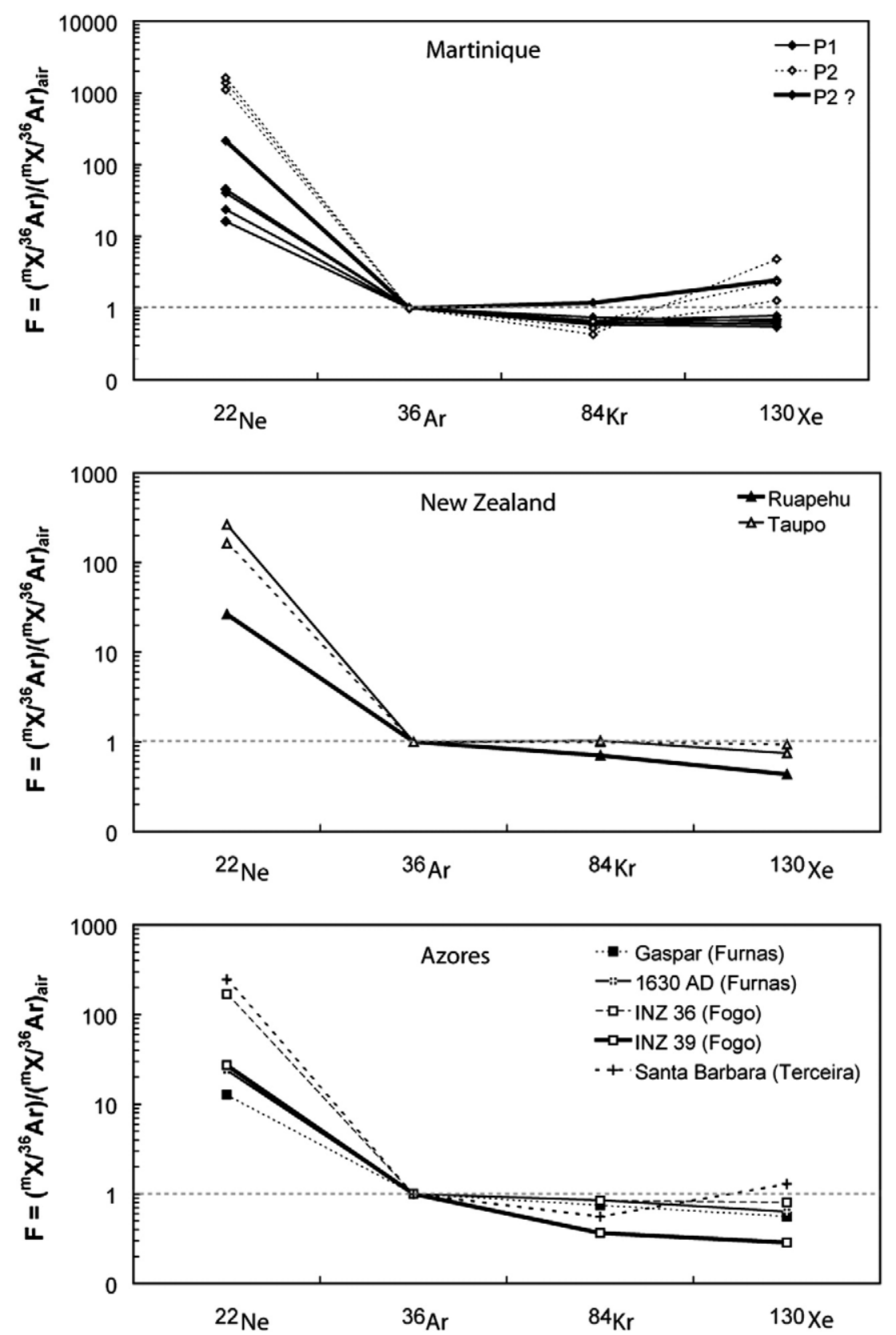

Fig. 2. Fractionation factors for pumices from Martinique, New Zealand and Azores. The patterns do not depend on geological setting, or on pumice age, or eruption intensity. However they are similar for the same eruption (Martinique).

that both elemental and isotopic fractionations are due to a single physical process.

\section{Modeling and discussion}

Pinti et al. (1999) explain their measurements by a preferential diffusion of neon over argon through bubble walls after pumice quenching in the Plinian plume. In this case, vesicles do not contain gas at the beginning of diffusion. We can test this assumption for neon. We consider an extreme case where diffusion occurs at ambient temperature after deposition. We choose a bubble shell of $10 \mu \mathrm{m}$ wall thickness, a value that is consistent with the range measured by Toramaru (1990). One can use the simple diffusion law $x^{2}=D t$, with $D$ the diffusion coefficient at ambient temperature, $x$ the shell width and $t$ the time. Diffusion coefficients $(D)$ of noble gases at low temperatures for a given chemical composition are difficult to estimate. Most of the experiments are conducted at high temperatures and the coefficients at lower temperatures are extrapolated via the Arrhenius law. In this study, we have selected diffusion data in both natural and synthesized samples with high $\mathrm{SiO}_{2}$ contents, close to the composition of our samples (Fig. 5).

We calculate that neon needs 300 years to reach the bubble using a diffusion coefficient of $10^{-20} \mathrm{~m}^{2} \mathrm{~s}^{-1}$. This time is less than the minimum age for our pumices except for Ruapehu and St. Helens samples that both have less than 25 years old. After 300 years, we can consider that the equilibrium is reached, i.e. the chemical potentials are equal, equivalent to the equality of partial pressure from each side of the shell. Therefore the ${ }^{22} \mathrm{Ne}$ volume fraction in vesicles should be equal to the air one, which is $1.68 \times 10^{-6}$.

For P1 pumice, Martel et al. (2000) have estimated that the isolated voids apparent size is comprised between 1 and $100 \mu \mathrm{m}$. Then, for a $100-\mu \mathrm{m}$ in diameter bubble, we obtain $8.8 \times 10^{-13}$ cCSTP ${ }^{22} \mathrm{Ne} /$ bubble. Bernard et al. (2007) have realized measurements using the triple weighting method to establish both connected and closed 


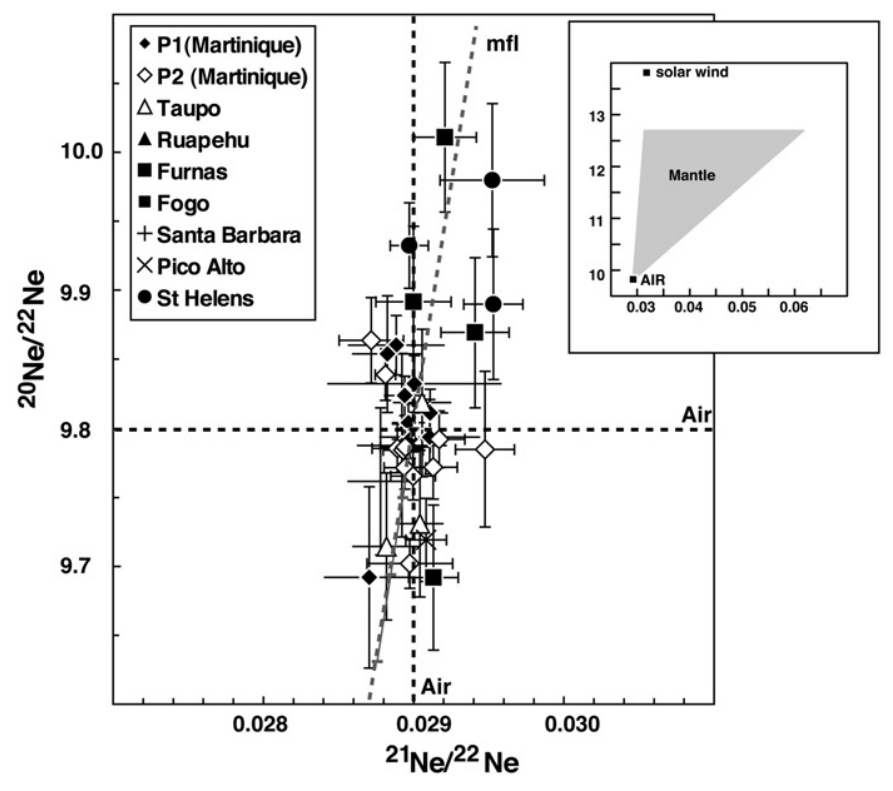

Fig. 3. Neon isotopic ratios measured in pumice. In the top-right corner, we show the same diagram that includes mantle-derived rocks (Raquin, 2008). It is important to note the span of scales. Our measurements are quite close to the air value, suggesting that an air-derived component is the origin of the trapped noble gases. This component could originate from water coming from the slab, or due to a more superficial contamination (aquifer, geothermal system...).

porosity in P1 samples. Using these data and a mean density of $0.9 \mathrm{~g} /$ $\mathrm{cm}^{3}$ (Villemant and Boudon, 1999), we are able to estimate the number of preserved vesicles per mass unit. We have there access to the theoretical ${ }^{22} \mathrm{Ne}$ concentration for a sample. The results seem to be in good agreement with the experimental values (Table 2).

Two conclusions can be reached here. First the final ${ }^{22} \mathrm{Ne}$ amount is likely to be proportional to the preserved vesicle volume as concluded by Pinti et al. (1999). Second, 300 years after deposition, we can consider a priori that the measured ${ }^{22} \mathrm{Ne}$ could be linked to the air via diffusion through bubble walls.

We can test this assumption for another gas, like argon. Its diffusion coefficient is about $10^{-40} \mathrm{~m}^{2} / \mathrm{s}$ at ambient temperature.

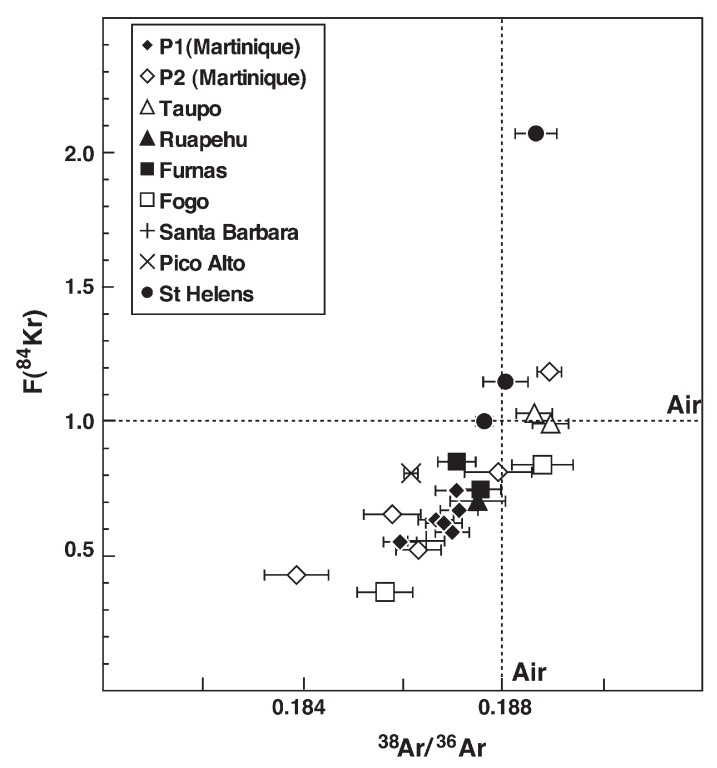

Fig. 4. ${ }^{84} \mathrm{Kr}$ fractionation factor, $F\left({ }^{84} \mathrm{Kr}\right)$, versus ${ }^{38} \mathrm{Ar} /{ }^{36} \mathrm{Ar}$. Measurements show an elemental fractionation between argon and krypton. They also show an isotope fractionation for argon isotopes. Moreover, a good correlation appears between $F\left({ }^{84} \mathrm{Kr}\right)$ and ${ }^{38} \mathrm{Ar} /{ }^{36} \mathrm{Ar}$.
From the same equation for diffusion, argon needs $3.10^{22}$ years to get through the $10 \mu \mathrm{m}$ shell. It means, it is impossible to add argon to the sample via diffusion even at higher temperature. We can easily suppose the same result for krypton and xenon, for which diffusivity coefficients are lower than for argon. To conclude, the model of Pinti et al. (1999) does not explain the heavy noble gas abundances. We propose here a new model.

\subsection{Kinetic degassing}

We can consider two physical degassing models for the vesiculation process. At the onset of vesicle growth, when exsolution of noble gases is driven by diffusion, neon enters faster than argon due to its higher diffusivity (Fig. 6). When sufficient time has passed for equilibrium to be established, the solubilities of the gases control partitioning of neon and argon between vesicles and melt (Fig. 7). Thus, our results require a kinetic model to explain both neon enrichment and argon isotopic fractionation.

Proussevitch et al. (1993) developed a cell model describing diffusion-induced growth of closely spaced bubbles in magma. Our model is based on that of Proussevitch et al. (1993) (Fig. 7). The main volatile in silicic magma is water. Noble gases are considered as trace elements. They do not contribute to bubble growth. We make the assumption that bubbles are already formed to facilitate the calculation. Any bubble with its finite portion of surrounding silicate melt forms a polygonal elementary cell, whose geometry can be approximated as spherical. In spherical coordinates, the diffusion equation for any volatile from melt into the bubble is:

$\frac{\partial c}{\partial t}=D \frac{1}{r^{2}} \frac{\partial}{\partial r}\left(r^{2} \frac{\partial c}{\partial r}\right)$

where $C$ is the concentration of volatile in melt and $D$, its diffusivity. Let us define initial and boundary conditions at the bubble surface $(r=a)$ and at the melt shell surface $(r=S)$. They are,

$c(r, 0)=c_{0}(r>a, t=0)$

$c(a, t)=K P_{i}(t)(r=a, t>0)$

$\left(\frac{\partial c}{\partial r}\right)_{r=s}=0(t>0)$

Eq. (2a) expresses the initial uniform distribution of dissolved gases in the magma. Eq. (2b) represents the solubility rule defining the equilibrium volatile concentration on the bubble-melt interface according to the pressure inside the bubble. The outer surface of the elementary cell is not permeable for the volatiles, and then the flux is equal to zero (Eq. 2c).

The mass balance of the gas at the interface can be obtained by equating the variation of its amount in the bubble to the flux through the interface,

$\frac{\mathrm{d}}{\mathrm{d} t}\left(\frac{4}{3} \pi a^{2} \rho_{g}\right)=4 \pi a^{2} \rho_{m}\left(\frac{\mathrm{d} C}{\mathrm{~d} r}\right)_{r=a}$,

where $\rho_{\mathrm{g}}$ and $\rho_{\mathrm{m}}$ are respectively the density of vapor and melt. The left-hand side of the equation shows the accumulation of the gaseous mass in the bubble, and the right-hand side is diffusive flux of dissolved volatiles through the bubble-melt interface. After simple rearrangement using the perfect gas law, Eq. (3) can be written as,

$\frac{\mathrm{d}}{\mathrm{d} t}\left(P_{i}\right)=\frac{3 R T D \rho_{m}}{a M}\left(\frac{\mathrm{d} C}{\mathrm{~d} r}\right)_{r=a}$. 
$1000 / \mathrm{T}\left(\mathrm{K}^{-1}\right)$

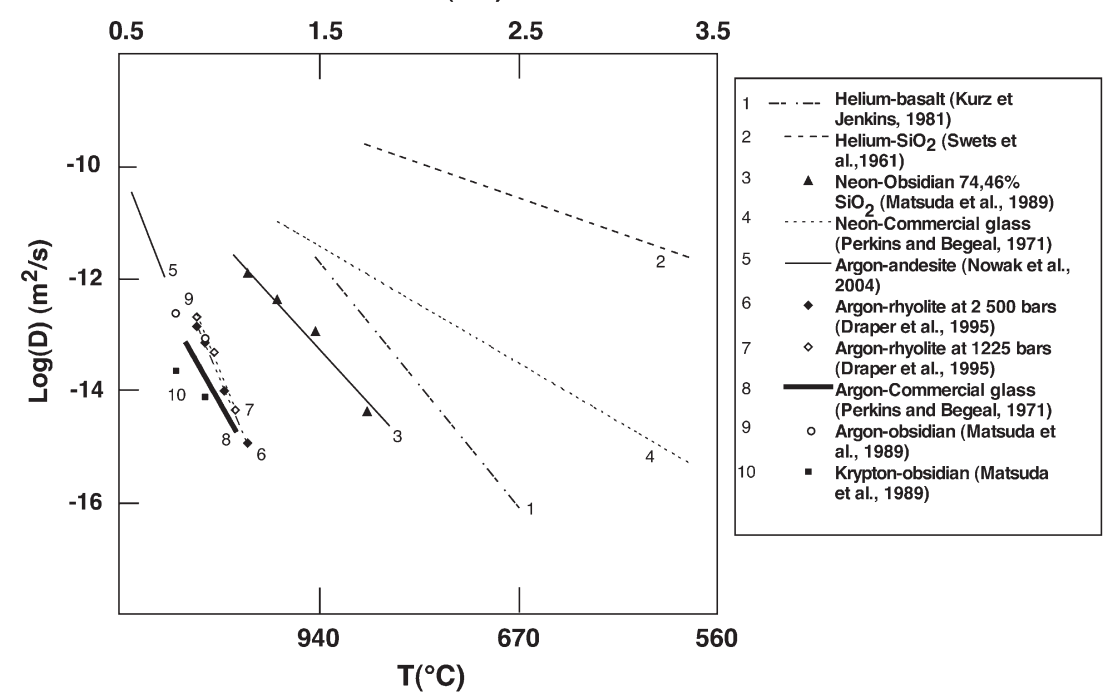

Fig. 5. Noble gas diffusion coefficients.

Data from Kurz and Jenkins (1981), Swets et al. (1961), Matsuda et al. (1989), Perkins and Begeal (1971), Drapper and Carroll (1995), and Nowak et al. (2004).

\subsection{Solving problem for Montagne Pelée eruptions}

For New Zealand, St. Helens and Azores, only one pumice per eruption was analyzed making difficult to understand a global magma degassing dynamic during these Plinian eruptions. Nevertheless, we were able to carry out a more systematic study on the P1 and P2 wellstudied eruptions from Martinique with several pumices analyzed for each eruption.

The analyzed P1 pumices are interesting because they were sampled at the same location, Morne Lénard. All samples from P1 eruption are acid andesite $\left(\mathrm{SiO}_{2}\right.$ range: $\left.59.2-61.2 \%\right)$ with very similar composition (Villemant and Boudon, 1999). Phase equilibrium studies allow pre-eruptive conditions to be known. Before the eruption, the magma was stored at $2 \pm 0.5 \mathrm{kbar}$ and $900{ }^{\circ} \mathrm{C}$ (Martel et al., 1998).

Many studies have shown that solubility does not depend on temperature (Lux, 1987; Drapper and Carroll, 1995; Shibata et al., 1998). Yamamoto and Burnard (2005) pointed out that for tholeitic basalts gas solubilities do not deviate from Henrian behavior between $50 \mathrm{MPa}$ and $250 \mathrm{MPa}$. Therefore, solubility seems to be linear with pressure. These pressures correspond to our nucleation pressure before fragmentation. The coefficients used are $2.6 ; 1.5 ; 1.1 ; 0.83 \times 10^{-4} \mathrm{ccSTP} / \mathrm{g} \mathrm{bar}{ }^{-1}$ for $\mathrm{He}$, $\mathrm{Ne}, \mathrm{Ar}, \mathrm{Kr}$, and Xe respectively (Data from Shibata et al., 1998 for neon and from Lux, 1987 for the other gases).

Diffusivity for each gas is obtained by using Fig. 4. For argon, Drapper and Carroll (1995) measured a diffusivity in rhyolite at $850{ }^{\circ} \mathrm{C}$ and $2.5 \mathrm{kbar}$ around $10^{-13} \mathrm{~m}^{2} \mathrm{~s}^{-1}$. We decided to use a diffusion coefficient 800 times faster for neon and for heavy noble gases equal to $0.4 \times 10^{-13} \mathrm{~m}^{2} \mathrm{~s}^{-1}$ using the database presented in

Table 2

Connected porosity $\left(\Phi_{\mathrm{con}}\right)$, closed porosity ( $\left.\Phi_{\text {clos }}\right)$, voids space, total closed bubble in $1 \mathrm{~g}$ of rock, the calculated ${ }^{22} \mathrm{Ne}$ abundance and the measured ${ }^{22} \mathrm{Ne}$ abundance in P1eruption pumices at Mt Pelée. Uncertainties are around 10\%.

\begin{tabular}{llcllll}
\hline Sample & $\begin{array}{l}\Phi_{\text {con }} \\
(\%)\end{array}$ & $\begin{array}{l}\Phi_{\text {clo }} \\
(\%)\end{array}$ & $\begin{array}{l}\text { Void } \\
(\%)\end{array}$ & Closed bubbles & $\begin{array}{l}{ }^{22} \text { Ne calculated } \\
(\mathrm{ccSTP} / \mathrm{g})\end{array}$ & $\begin{array}{l}{ }^{22} \text { Ne measured } \\
(\mathrm{ccSTP} / \mathrm{g})\end{array}$ \\
\hline $\mathrm{F}$ & 63.1 & 9.4 & 72.5 & $1.5 \times 10^{5}$ & $1.2 \times 10^{-7}$ & $8.7 \times 10^{-8}$ \\
$\mathrm{G}$ & 61.7 & 8 & 69.7 & $1.18 \times 10^{5}$ & $9.3 \times 10^{-8}$ & $9 \times 10^{-8}$ \\
$\mathrm{D} 3$ & 54.1 & 11 & 65.7 & $1.53 \times 10^{5}$ & $1.2 \times 10^{-7}$ & $1.2 \times 10^{-7}$ \\
$\mathrm{H}$ & 57.8 & 8.6 & 66.4 & $1.21 \times 10^{5}$ & $9.6 \times 10^{-8}$ & $7.8 \times 10^{-8}$ \\
\hline
\end{tabular}

Fig. 5. For isotope diffusion, we used the simple relation with mass often quoted in the literature (Craig and Lupton, 1976; Kaneoka, 1980):

$D^{38} \mathrm{Ar} /{ }^{36} \mathrm{Ar}=\sqrt{\frac{m_{36}}{m_{38}}} \times D^{36} \mathrm{Ar}$,

where $m_{36}$ and $m_{38}$ are argon isotope mass.

In our model, we need initial noble gas ratios, which are unknown. However, it seems that an atmospheric composition could represent the starting point for most cases. When seawater is dissolved in MORB-type magma, the fractionation factors are quite similar to the
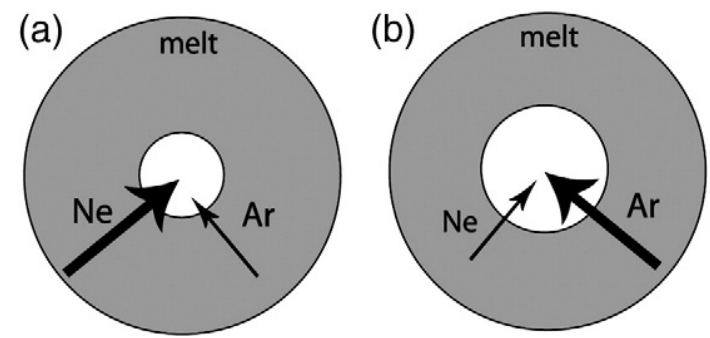

Fig. 6. Schematic representation of kinetic (a) and equilibrium (b) degassing state with respect to $\mathrm{Ne}$ and $\mathrm{Ar}$.

Modified after Aubaud et al. (2004).

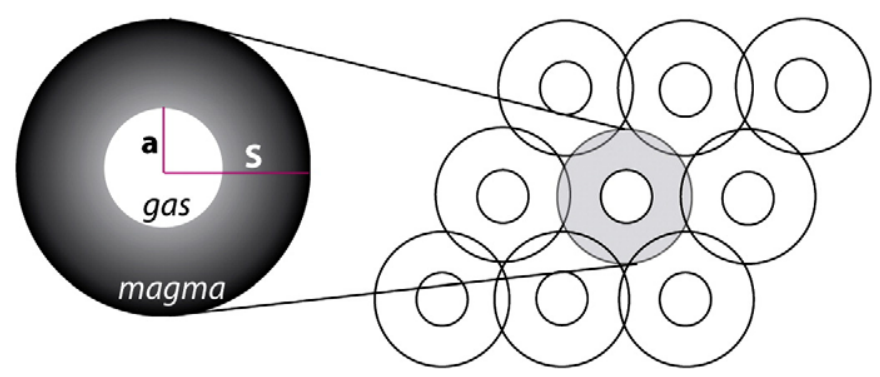

Fig. 7. Description of the model. Each bubble is surrounded by a finite volume of melt. The elementary cell is spherical with a bubble at its center. Modified after Proussevitch et al. (1993). 
Table 3

Noble gas fractionation factors in seawater, seawater solubilized in MORB-type magma and in andesite-type magma. Solubility data from Lux (1987).

\begin{tabular}{llll}
\hline Composition & $F(22)$ & $F(84)$ & $F(130)$ \\
\hline Seawater & 0.249 & 2 & 3.4 \\
Seawater + MORB-type magma & 1 & 1.45 & 1.06 \\
Seawater + andesite-type magma & 0.81 & 1.48 & 1.83 \\
\hline
\end{tabular}

air values (Table 3). Water bearing atmospheric noble gases can be introduced by the dehydration of the slab in subduction zones or by a shallow contamination origin for the heavy noble gases.

Using all these data, Eq. (4) is solved using Partial Differential Equation Solver of Matlab@. Model calculations are presented on Fig. 8a, b. Our model explains the neon enrichment without requiring a post-quenching diffusion and also explains the value of ${ }^{20} \mathrm{Ne} /{ }^{22} \mathrm{Ne}$ around 9.8 for very short time on the order of tens of seconds. For the same time, the calculated ${ }^{38} \mathrm{Ar} /{ }^{36} \mathrm{Ar}$ is around 0.1855 which is closed to the P1 analyzed values in the range of $0.1859 \pm 0.0003$ and $0.1871 \pm$ 0.0004 . This is in agreement with the result obtained in the literature on magma ascent rates in explosive eruptions. In Proussevitch and Sahagian (2005), disequilibrium magma degassing drives their numerical model of volcanic eruption mechanisms. They observed that the eruption occurs within 2 min of the trigger, showing the rapidity of the degassing. Humphreys et al. (2008) determined also a very rapid ascent time in the order of 2-3 min using $\mathrm{H}_{2} \mathrm{O}$ diffusion profiles in imperfectly trapped melt inclusions.

However, using only $F\left({ }^{84} \mathrm{Kr}\right)$ and ${ }^{38} \mathrm{Ar} /{ }^{36} \mathrm{Ar}$, we can observe that few hours explain better our data. This is in agreement with the time plagioclase nucleation determined by Couch et al. (2003a). This required up to $5 \mathrm{~h}$. Moreover, Bardintzeff et al. (1989) proposed a P1-eruption duration in the order of few hours based on grain-size and tephra volume consideration.

The time difference between elemental and isotopic fractionations is probably due to our uncertainties on diffusion coefficient and on elemental compositions (e.g. $F^{84} \mathrm{Kr}-$ cf Table 3 ).

\section{Conclusions}

Noble gases trapped in closed vesicles of pumice give new constraints on explosive eruption dynamics. Measured fractionation factors show that the content of noble gases and their elementary ratios are independent of the eruption age, the geological setting and the eruption intensity. Notwithstanding noble gas abundance patterns that are similar for pumices from the same eruption. Argon isotopic fractionations were also measured. ${ }^{38} \mathrm{Ar} /{ }^{36} \mathrm{Ar}$ fractionation can only be induced by disequilibrium process, such as kinetic degassing.

We have developed a new model to explain such observations. We used a cell model based on that of Proussevitch et al. (1993) describing

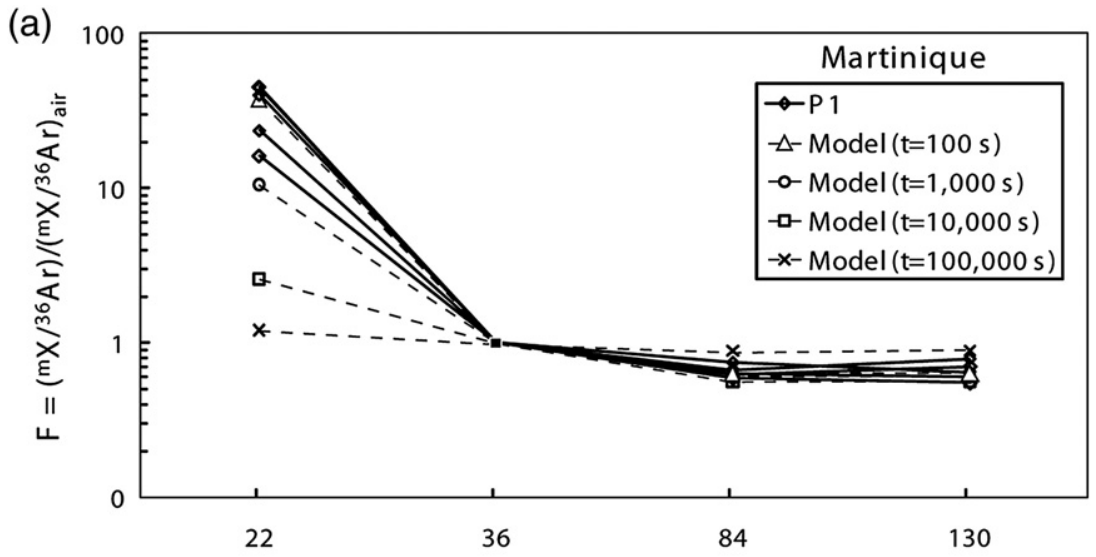

(b)

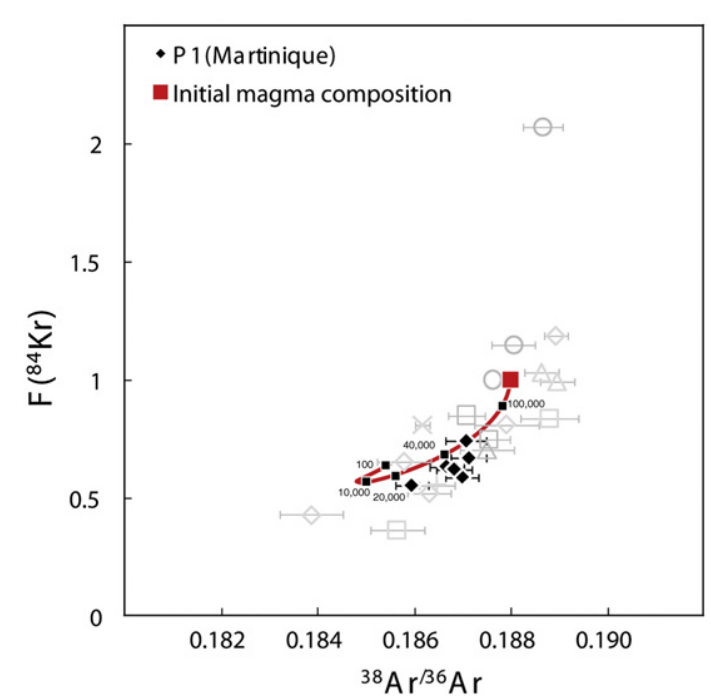

Fig. 8. a. Measured and calculated fractionation factors for the P1 eruption at Montagne Pelée as a function of time. The numerical model is able to explain all data obtained in the pumice, with time in the order of few hundreds of seconds. b. ${ }^{84} \mathrm{Kr}$ fractionation factor versus isotopic ratio ${ }^{38} \mathrm{Ar} /{ }^{36} \mathrm{Ar}$ for P1 eruption. The calculated value is close to the measured values. 
diffusion of noble gases in a magma shell surrounding a preexisting bubble. Our model is able to determine characteristic times of magma ascent in the order of few hundred seconds, in agreement with previous estimates.

\section{Acknowledgements}

We are grateful to Edouard Kaminski for fruitful discussions on physical processes during Plinian eruptions. We thank Maria Zamora and S. Tait for the pumice samples of Montagne Pelée. P. Madureira and Joao Carlos Nunes are thanked for their help during sampling in Azores. We thank also Pete Burnard and the anonymous reviewer for his very helpful review. This is IPGP contribution $\mathrm{N}^{\circ} 2626$.

\section{References}

Aubaud, C., Pineau, F., Jambon, A., Javoy, M., 2004. Kinetic disequilibrium of C, He, Ar and carbon isotopes during degassing of mid-ocean ridge basalt. Earth and Planetary Science Letters 22, 391-406.

Bardintzeff, J.M., Miskovsky, J.C., Traineau, H., Westercamp, D., 1989. The recent pumice eruptions of Mt Pelee volcano, Martinique. 2. Grain-size studies and modeling of the last Plinian phase-p. Journal of Volcanology and Geothermal Research 38, 35-48.

Bernard, M.-L., Zamora, M., Géraud, Y., Boudon, G., 2007. Transport properties of pyroclastic rocks from Montagne Pelée volcano (Martinique, Lesser Antilles). Journal of Geophysical Research 112, B05205.

Calvert, A., Moore, R., McGeehin, J., Rodrigues da Silva, A., 2006. Volcanic history and ${ }^{40} \mathrm{Ar} /{ }^{39} \mathrm{Ar}$ and ${ }^{14} \mathrm{C}$ geochronology of Terceira Island, Azores, Portugal. Journal of Volcanology and Geothermal Research 156, 103-115.

Christenson, B., 2000. Geochemistry of fluids associated with the 1995-1996 eruption of Mt Ruapehu, New Zealand: signatures and processes in the magmatichydrothermal system. Journal of Volcanology and Geothermal Research 97, 1-30.

Cole, P., Queiroz, G., Wallenstein, N., Gaspar, J., Duncan, A., Guest, J., 1995. An historic subplinian/phreatomagmatic eruption: the $1630 \mathrm{AD}$ eruption of Furnas volcano, Sao Miguel, Azores. Journal of Volcanology and Geothermal Research 69, 117-135.

Couch, S., Harford, C.L., Sparks, R.S.J., Carroll, M.R., 2003. Experimental constraints on the conditions of formation of highly calcic plagioclase microlites at the Soufrire Hills Volcano, Montserrat. Journal of Petrology 44 (8), 1455-1475.

Craig, H., Lupton, J.E., 1976. Primordial neon, helium, and hydrogen in oceanic basalts. Earth and Planetary Science Letters 31 (3), 369-385.

Drapper, D., Carroll, M., 1995. Argon diffusion and solubility in silicic glasses exposed to an Ar-He gas mixture. Earth and Planetary Science Letters 132, 15-24.

Humphreys, M.C.S., Menand, T., Blundy, J.D., Klimm, K., 2008. Magma ascent rates in explosive eruptions: constraints from $\mathrm{H} 2 \mathrm{O}$ diffusion in melt inclusions. Earth and Planetary Science Letters 270 (1-2), 25-40.

Kaminski, E., Jaupart, C., 1998. The size distribution of pyroclasts and the fragmentation sequence in explosive volcanic eruption. Journal of Geophysical Research 103 , 29759-29779.

Kaneoka, I., 1980. Rare gas isotopes and mass fractionation: an indicator of gas transport into or from a magma. Earth and Planetary Science Letters 48, 284-292.

Kurz, M., Jenkins, W., 1981. The distribution of helium in oceanic basalt glasses. Earth and Planetary Science Letters 53, 41-54.
Lux, G., 1987. The behavior of noble gases in silicate liquids: solution, diffusion, bubbles and surface effects, with application to natural samples. Geochemica at Cosmochemica Acta 51, 1549-1560.

Mangan, M., Sisson, T., 2000. Delayed disequilibrium degassing in rhyolite magma: decompression experiments and implications for explosive volcanism. Earth and Planetary Science Letters 183, 441-455.

Martel, C., Pichavant, M., Bourdier, J.L., Traineau, H., Holtz, F., Scaillet, B., 1998. Magma storage conditions and control of eruption regime in silicic volcanoes: experimenta evidence from Mt. Pelée. Earth and Planetary Science Letters 156 (1-2), 89-99.

Martel, C., Bourdier, J.L., Pichavant, M., Traineau, H., 2000. Textures, water content and degassing of silicic andesites from recent Plinian and dome-forming eruptions at Mount Pelée volcano (Martinique, Lesser Antilles arc). Journal of Volcanology and Geothermal Research 96 (3-4), 191-206.

Matsuda, J., Matsubara, K., Yajima, H., Yamamoto, K., 1989. Anomalous Ne enrichment in obsidians and darwin glass: diffusion of noble gases in silica-rich glasses. Geochemica et Cosmochemica Acta 53, 3025-3033.

Moore, R., 1990. Volcanic geology and eruption frequency, Sao Miguel, Azores. Bulletin of Volcanology 52, 602-614.

Nowak, M., Schreen, D., Spickenbom, K., 2004. Argon and CO2 on the race track in silicate melts: a tool for the development of a $\mathrm{CO} 2$ speciation and diffusion model. Geochemica et Cosmochemica Acta 68, 5127-5138.

Perkins, W., Begeal, D., 1971. Diffusion and permeation of He, Ne, Ar, Kr, D2 through silicon thin film. Journal of Chemical Physics 54, 1683-1694.

Pinti, D., Wada, N., Matsuda, J., 1999. Neon excess in pumice: volcanological implications. Journal of Volcanology and Geothermal Research 88, 279-289.

Proussevitch, A., Sahagian, D., 2005. Bubbledrive-1: a numerical model of volcanic eruption mechanisms driven by disequilibrium magma degassing. Journal of Volcanology and Geothermal Research 143, 89-111.

Proussevitch, A., Sahagian, D., Anderson, A., 1993. Dynamics of diffusive bubble groxth in magmas: isothermal case. Journal of Geophysical Research 98, 22283-22307.

Raquin, A. (2008). Nouvelles contraintes sur les modèles d'origine et d'évolution des gaz rares dans le manteau terrestre. Ph.D. thesis. Paris.

Scandone, R., Cashman, K., Malone, S., 2007. Magma supply, magma ascent and the style of volcanic eruptions. Earth and Planetary Science Letters 253, 513-529.

Shibata, T., Takahashi, E., Matsuda, J., 1998. Solubility of neon, argon, krypton and xenon in binary and ternary silicate systems: a new view on gas solubility. Geochemica et Cosmochemica Acta 62, 1241-1253.

Sparks, R., 1978. The dynamics of bubble formation and growth in magmas: a review and analyses. Journal of Volcanological and Geothermal Research 3, 1-37.

Swets, D., Lee, R., Franck, R., 1961. Diffusion coefficients of helium in fused quartz. Journal of Chemical Physics 34, 17-22.

Thomas, N., Jaupart, C., Vergniolle, S., 1994. On the vesicularity of pumice. Journal of Geophysical Research 99, 15633-15644.

Toramaru, A., 1990. Measurement of bubble size distributions in vesiculated rocks with implications for quantitative estimation processes. Journal of Volcanology and Geothermal Research 43, 71-90.

Villemant, B., Boudon, G., 1999. $\mathrm{H}_{2} \mathrm{O}$ and halogen $(\mathrm{F}, \mathrm{Cl}, \mathrm{Br})$ behaviour during shallow magma degassing processes. Earth and Planetary Science Letters 168 (3-4) $271-286$.

Westercamp, D., Traineau, H., 1983. The past 5000 years of volcanic activity at Mt. Pelée Martinique (FWI): implication for assesment of volcanic hazards. Journal of Volcanology and Geothermal Research 17, 159-185.

Wilson, C., Houghton, B., McWilliam, M., Lanphere, M., Weaver, S., Briggs, R, 1995. Volcanic and structural evolution of Taupo Volcanic Zone, New Zealand: a review. Journal of Volcanology and Geothermal Research 68, 1-28.

Yamamoto, J., Burnard, P., 2005. Solubility controlled noble gas fractionation during magma degassing: implication for noble gas compositions of primary melts of OIB and MORB. Geochemica et Cosmochemica Acta 69, 727-734. 